appropriate control. It is the mayor who represents the city community in all its external relations. If the president is unable to perform his duties, the vice president assumes them. The latter also shares with the president the matter of managing the magistrate and the city's municipal institutions, in accordance with the division of responsibilities established by the mayor, which will be reported to the council.

The mayor was in charge of all employees and employees of the gmina, in respect of whom he had the right of disciplinary authority. Using this power, the president could temporarily remove the culprit from office, keep part of his salary. However, the application of disciplinary measures must be notified to the council, which finally resolved the conflict.

The mayor, as well as his deputy, is responsible for his actions and the actions of his subordinates in the affairs of the city community before the city council, and in matters entrusted to him by the state government, respectively, before him in the person of the Governor.

It is concluded that wealthy communities of such large cities as Drohobych, Kolomyia, Krakow, Lviv, Stanislav, Stryy, Ternopil had more opportunities to realize their potential, but also small towns and cities, having the right to keep some of the profits taxes and their careful use for their own needs, have had a tangible effect. Even though the system of communal self-government had its shortcomings, communities became wealthier, their opportunities grew, and civic activity in local self-government became a useful school of public life.

Keywords: city self-government, gmina, city community, city council, mayor, city council, burgoma.

DOI: 10.33766/2524-0323.92.27-37

УДК 316:94(477)

Л. Г. Матвєева, доктор юридичних наук, доцент, завідувачка кафедри теорії та філософії права Одеського державного університету внутрішніх справ (м. Одеса, Україна) e-mail: liliya.matveeva@i.ua iDhttps://orcid.org/0000-0002-8402-5584

Л. Б. Тарасенко, кандидат історичних наук, доцент, професорка кафедри теорії та філософії права Одеського державного університету внутрішніх справ (м. Одеса, Україна) e-mail: tarasenko_lb@ukr.net iD ttps:/ / orcid.org/0000-0002-0927-8994

\title{
ПРАВОВЕ ТА СОЩАЛЬНЕ СТАНОВИЩЕ БАТРАЦТВА В СЕЛАХ ДОНБАСУ В РОКИ НОВОЇ ЕКОНОМІЧНОЇ ПОЛІТИКИ (У КОНТЕКСТІ ПОВСЯКДЕННОСТІ)
}

У статті досліджуються особливості правового та соціального становища батрацтва Донбасу в роки нової економічної політики, його праці та побуту. У часи непівських перетворень розпочалися значні зрушення в соціальній структурі селянства. Особливості земельної політики радянської держави цього періоду, зокрема легалізація оренди землі та найманої праці в сільькогосподарському виробництві, відкрили певні можливості

(C) Матвєєва Л. Г.,

Тарасенко Л. Б., 2020 
для розвитку індивідуального селянського господарства, причому дозволялося певне зростання капіталістичних елементів села під контролем державних органів. Проте, 3 іншого боку, погіршувалося економічне становище маломіщних господарств, унаслідок чого сформувалася досить складна соціальна категорія сільського населення, яке жило за рахунок продажу своєї праці, - батрацтво.

У статті, серед іншого, використано документи та матеріали, що зберігалися в Державному архіві Донецької області та Державному архіві Луганської області і зараз, із відомих причин, є недоступними для вивчення.

Ключові слова: НЕП, сільське господарство, батрацтво, оренда землі, наймана праця.

Постановка проблеми. Сучасні процеси в аграрному секторі економіки України стимулюють зростання значного інтересу науковців до дослідження специфічних особливостей перебігу аграрних перетворень, зокрема виробничої діяльності та життя сільського населення, що мали місце в українському селі в 20-ті рр. XX ст. під час нової економічної політики більшовиків. 3 метою подолання економічної кризи та збереження політичної влади більшовики використали світовий досвід організації сільськогосподарського виробництва на ринковій основі. Вони надали селянству певні можливості вільно господарювати, працювати на себе, створили умови для розгортання приватної ініціативи та підприємнищтва, завдяки чому отримали значні позитивні досягнення. Проте зазначене закономірно призвело до інтенсивного соціального розшарування сільського населення. Зростання заможної куркульської та середняцької верстви відбувалося за рахунок використання найманої праці найбідніших верств селянства.

Об'єктивне вивчення досвіду минулого має не лише пізнавальне, але й важливе практичне значення. Без його детального та критичного аналізу важко уникнути ускладнень на шляху до ефективного реформування сільськогосподарського виробництва в сучасних умовах, чим і визначається актуальність даної теми.

Аналіз останніх досліджень і публікацій. Вагомий внесок у дослідження різнобічних аспектів розвитку українського села зазначеної доби внесли вітчизняні дослідники О. Ганжа, В. Калініченко, С. Кульчицький, С. Лях, В. Смирнов та інші науковці. Вони з позицій якісно нового рівня наукового осмислення розвитку сільського господарства в добу НЕПу висвітлювали соціально-економічні аспекти селянського господарства, пошук селянами оптимальних форм господарювання, роль НЕПу в активізації трудової діяльності українського селянства та зробили вагомий внесок у розробку складних питань щодо соціально-економічних перетворень більшовищької партії в українському селі протягом періоду відродження та розвитку товарно-ринкових відносин у 20-і рр. XX ст. Водночас багато питань на регіональному чи місцевому рівнях досліджені недостатньо, потребують більш докладного вивчення та залучення до наукового обігу нових матеріалів.

Формулювання цілей. Метою даної статті є дослідження соціального становища батрацтва Донбасу та його повсякденних трудових практик, невідривно пов' язаних із життям і побутом селянства, у роки нової економічної політики, до якої вдалася державна (більшовицька) партія в 20-ті рр. XX ст. 3 метою виходу 3 політичної та економічної кризи. 
Виклад основного матеріалу. Одним із наслідків НЕПу стало формування досить складної соціальної категорії сільського населення, яке жило за рахунок продажу своєї пращі, - батрацтва. Відносини найму та оренди, легалізовані більшовиками $з$ початком НЕПу, сприяли диференціації селянства. 3 одного боку зростала заможність переважної більшості селян, а з іншого - відбувалося погіршення економічного становища частини маломіцних господарств [1, с. 42].

Як відомо, державна партія не мала чіткого стратегічного плану проведення нової економічної політики. НЕП впроваджувався певними кроками партійнодержавного керівництва, яких вимагала на той чи інший момент ситуація, що складалася.

Основним нормативним актом, на основі якого відбувалося регулювання правових відносин в УСРР у початковий період НЕПу, був Кодекс законів про працю (КЗПП) УСРР $1922 \mathrm{p}$.

Норми КЗПП УСРР регулювали трудові відносини, організацію праці, їі оплату й охорону в умовах нової економічної політики. Норми Кодексу поширювалися на всіх осіб, які працювали за наймом, та були обов'язковими для всіх підприємств, установ і господарств, а також усіх осіб, які застосовували найману праџю за винагороду. Норми КЗПП встановлювали 8-годинний робочий день, а для осіб від 16 до 18 років, для осіб розумової та конторської праці і тих, хто працював на підземних роботах, тривалість робочого часу не могла перевищувати 6 годин. Не допускалася понаднормова робота. Усім працівникам встановлювався щотижневий відпочинок не менше 42 годин. Кодекс регламентував питання, пов'язані з учнівством, працею жінок і неповнолітніх, містив норми про охорону пращі, про профспілки та ïx органи на підприємствах, в установах і господарствах, урегульовував питання про соціальне страхування осіб найманої пращі, передбачаючи надання різних видів допомоги (при захворюванні, тимчасовій утраті працездатності, безробітті, інвалідності, у зв'язку з доглядом за хворим членом сім'ї тощо) [2].

Але Кодекс був недосконалим і недієвим щодо сільького господарства, він переносив на сільськогосподарське виробництво норми фабрично-заводського законодавства, не враховував специфіку сільського господарства, сезонність робіт, не визначав умови найму, права наймачів і наймитів тощо, тому визначального впливу на соціальне становище батрацтва, організацію його праці та побуту не мав.

Розуміючи необхідність дієвої законодавчої регламентації розвитку сільского господарства, яке не могло в умовах нової економічної політики розвиватися без використання найманої праці, Рада Народних Комісарів Союзу РСР у квітні 1925 р. затвердила Тимчасові правила про умови застосування підсобної найманої праці в селянських господарствах трудового типу. Вони до кінщя НЕПу визначали застосування найманої праці на селі. Умови найму батрацтва відтепер визначалися добровільними письмовими угодами між наймачем і наймитом, у яких було вказано вид праці, на яку наймалися батраки, термін найму, робочий час, розмір, види та терміни виплати зарплатні тощо. Угоди мали реєструватися в сільрадах. За угодою сторін допускався подовжений робочий день (білыше 8 годин) в окремі сільськогосподарські періоди. Дозволялося використання в наймах у селянських господарствах підлітків із 14 років, а для особливо легких робіт - із 12 років. Наймач зобов' язаний 
був надати наймиту один день на тиждень для відпочинку, а також надавати святкові дні, визначені законодавством. Угодою встановлювався розмір винагороди за працю, але не нижче за державний мінімум, встановлений для даної місцевості, а також терміни, вид і спосіб оплати пращі наймита. Наймач зобов' язаний був надати наймиту придатне для проживання приміщення, їжу такої ж якості, яка вживалася в сім'ї наймача. Зборонялася праця підлітків і вагітних жінок на тяжких та шкідливих для їхнього здоров’я роботах. У певних випадках передбачалося сощіальне страхування наймачами наймитів, визначався порядок звільнення наймитів.

Своєю чергою, наймити були зобов'язані виконувати роботу, передбачену угодою, дбайливо ставитися до майна наймача.

Для розгляду трудових спорів між наймачами та наймитами створювалися примирні комісії при волосних (районних) виконкомах, коли ж сторони не досягли угоди при розгляді справи в примирній комісії, справа передавалася до народного суду. Правила мали бути розміщені на видних місцях у всіх волосних (районних) виконкомах та сільських радах. Нагляд за дотриманням цих правил покладався на інспекцію праці [3].

Як бачимо, закон мав захищати права наймитів, але в реальному житті ці правила нерідко порушувалися, оскільки наймити залежали від волі наймача, боялися залишитися взагалі без роботи й працювали, не скаржачись.

До підприємницьких селянських господарств продовжували застосовуватися норми КЗПП, тому заможне селянство протягом НЕПу постійно їх порушувало, і влада до кінщя НЕПу нічого не могла з цим вдіяти.

У Донбасі внаслідок промислової спрямованості його економіки кількість батраків у сільськогосподарському виробництві була невеликою і майже не змінювалася протягом другої половини 20-х років: у 1925 р. - 16000 найманих робітників [4, с. 111-112], на 1 жовтня 1928 р. - 16602 [5, с. 242].

Але до роботи в наймах вдавалися не тільки безземельні селяни, а нерідко й селяни господарств із посівом від 1 до 4 десятин, оскільки не могли забезпечити себе, не вдаючись до сторонніх заробітків. Тож загальна кількість наймитів у 1923 р. складала 47,8 \% селянства, у 1928 р. - 33,1 \% [підраховано за: 6, арк. 37-38; 7, c. 284 -289]. А це вже навіть наприкінщі НЕПу третя частина селянства!

Отже, першим і важливим критерієм соціальної характеристики батрацтва $є$ його майновий стан, наявність невеликої кількості землі, що не могла прогодувати господаря із сім'єю.

Сільськогосподарському виробництву властивий сезонний характер. Зважаючи на господарську необхідність, наймачі наймали батраків на рокову, строкову, поденну і задільну роботу. Строкові наймані робітники наймалися на різні, але визначені строки. Задільні або здільні - це умовна назва робітників, які одержували заробітну плату за кінщевим результатом («за діло») [8, с. 13]. Так у Донбасі в 1925 р. на рокову та строкову роботу наймалися представники близько 61,2 \% селянських господарств, на поденну - 29,6 \%, на задільну - близько 9 \% [підраховано за: 9, с. 97].

Таким чином, іншим важливим критерієм соціальної характеристики батрацтва є тривалість роботи за наймом. Більшість наймитів намагалися знайти рокову та строкову роботу, бо вона була більш тривалою та забезпечувала хоч якусь стабільність існування. 
Розглянемо пересічні поденні ціни на робочі руки в сільському господарстві на деякі види робіт. Наприклад, у 1925 р. в селах Донбасу в середньому за сівбу ранньої ярини робітник із конем отримував 1,76 крб., піший робітник - 0,61 крб., робітниця - 0,43 крб., підліток - 0,28 крб. [підраховано за: 9, с. 96]. Для порівняння: в усій Україні за таку ж роботу робітник із конем отримував 1,70 крб., піший робітник 0,54 крб., робітниця - 0,40 крб., підліток - 0,28 крб. [9, с. 96].

Під час сінокосу тенденщія була такою ж: середня ціна по Україні на робочі руки робітника з конем складала 2,03 крб., пішого робітника - 0,91 крб., робітнищі - 0,57 крб., підлітка - 0,37 крб; в селах Донбасу, відповідно, 2,68 крб., 1,21 крб., 0,76 крб. та 0,49 крб. [9, с. 96].

Отже, ціна на працю - ще один важливий критерій соціальної характеристики батрацтва - залежала від статі та віку батрака, а також від того, піший цей робітник чи кінний. Робітник із конем отримував білыше, ніж піший, а чоловік отримував більше, ніж робітнищя. Дуже вигідно було наймати жінок, а ще краще - підлітків: ціна за працю робітниці складала приблизно 2/3 від ціни за працю робітника, підліткова ж не складала й половини.

Потрібно звернути увагу на те, що середні ціни на робочі руки в сільському господарстві Донбасу були дещо вищі, ніж в середньому по Україні. Це пов' язано 3 конкуренщією в наймі робочої сили, що складала сільському господарству промисловість Донбасу у зв'язку з її розвитком [10, арк. 52-53].

Зустрічалися випадки, коли використовувалася праця малолітніх (молодше за 12 років), що порушувало основні принципи трудового законодавства. Інколи підлітки працювали на тяжких і шкідливих роботах. Причини таких явищ крилися в безвідповідальності наймача [11, арк. 65].

Щодо форм оплати праці, то заробітна плата батракам виплачувалася в більшості випадків зерном, одягом, обробкою землі та грошима. Праця оплачувалася почасово, і термін видачі підпадав до збігання терміну договору.

Спостерігалася стійка тенденція зростання заробітної плати батрацтва протягом другої половини 20-х рp. XX ст., що свідчить про деяке підвищення рівня життя наймитів. Так середня заробітна плата батрака за квартал 1925 р. складала 15-20 карбованців [12, арк. 40]. У 1926 р. заробітна плата батрацтва зросла і в середньому дорівнювала 28 крб. на місяць, пастуха - 38 крб. Щоправда, у заробітну плату входила квартира та стіл, що надавав наймач; вони оцінювалися від 7-8 крб. до 15-17 крб. [11, арк. 67]. У наступні роки спостерігаємо зростання заробітної плати, що складала в 1928 р. у наймитів- дорослих 30 крб. на місяць, у 1929 р. - 32 крб., у підлітків, відповідно, - 16 крб. і 18 крб., у пастухів - 50 крб. і 55 крб., у підпасків - 24 крб. і 25 крб. [13, арк. 7].

Потребує уточнення, що наймачі не завжди дотримувалися умов оплати праці найманих робітників. Майже завжди зарплата видавалася натурою, не вказувалася якість продуктів, речей та одягу, через що батрак отримував не завжди те, що передбачалося при укладенні договору, а інше, - старий одяг, засмічене зерно тощо. Прожитковий мінімум при укладанні договору настільки не враховувався, що батраки в більшості випадків на зиму себе не забезпечували [11, арк. 67]. 
Необхідно додати, що й загалом в Україні грошова плата становила тільки частину всієї оплати праці наймита, причому не завжди переважну іï частину. Більшість наймитів, крім грошей $\mathrm{i}$ «натури» (продуктів харчування і речей широкого вжитку), отримували ще й «стіл» (харчування), одяг, рідше - житло, ще рідше - piзні послуги, незважаючи вже на те, що в цілому ряді випадків наймит працював лише за «натуру» або за одне харчування. 3 кожним роком «натура» витіснялася більш досконалою формою оплати праці - грошима, але продовжувала зберігати вагоме місце в зарплаті наймита. У Степу з його вищою товарністю господарства грошова оплата переважала натуральну [8, с. 59].

Добробут найманих сільськогосподарських робітників залежав не тільки від зарплати. Так значно погіршувалося життя наймитів через нестабільність соціального становища (загрозу безробіття, часту зміну місця роботи), а також сваволю наймачів - приватних власників.

Умови праці й побуту батрацтва були чи не найгіршими серед усіх груп трудящих і зовсім не відповідали встановленим санітарно-гігієнічним нормам, попри допомогу держави та їі заходи щодо контролю за додержанням трудового законодавства господарствами-наймачами робочої сили. Мешкали наймити в тісних вологих приміщеннях з низькою стелею, без кватирок. Улітку помешкання кишіло мухами. Спали батраки на підлозі, на одязі (шубах, кожухах; ними ж накривалися) $[14$, c. 16].

Загальновідомий важкий психологічний клімат, у якому доводилося працювати багатьом наймитам. Часто наймачі били своїх наймитів, особливо дітей, гвалтували наймичок, морили наймитів голодом, виганяли їх без виплати грошей. Були випадки перездачі в найм свого робітника іншому наймачу за підвищеною ціною, особливо в жнива [8, с. 62-63].

Убогий зовнішній вигляд, низький рівень життя і харчування були лише зовнішніми, найбільш «виразними» сторонами буденного життя наймита. Менш помітними, але більш суттєвими були економічні і виробничі умови, серед яких, насамперед, необхідно виділити важку монотонну працю, практичну відсутність вихідних днів і взагалі будь-якого вільного часу протягом сільськогосподарського сезону в поєднанні з безробіттям у решту днів, безперервні пошуки роботи, невпевненість у майбутньому. Ніхто з наймитів, особливо жінки та діти, не був застрахований від брутального поводження хазяїна-наймача, обману, штрафів, урізання зарплати. У часи ж погіршення сільськогосподарської кон'юнктури в сільському господарстві становище наймитів ставало просто безвихідним, і вони працювали за шматок хліба [8, с. 62-63].

Довшою була тривалість робочого дня селян-батраків. Для третьої частини малолітніх наймитів і підлітків та для 43,8 \% дорослих батраків Донбасу вона складала не менше 12 годин на добу [15, с. 29].

Партійними та профспілковими організаціями велася «боротьба з впливом приватного господаря на робітників шляхом групової та індивідуальної агітації останніх із роз' яснення класової лінії, а також через стінгазети та місцеву пресу» [10, арк. 57-59]. 
3 преси, наприклад, довідуємося, що на околищях Луганська багато польового та городнього господарства, яке користується найманою працею: сільське господарство сільськогосподарського технікуму, опитне поле, болгарські городи. Працює в них значна кількість жінок-батрачок. Це відсталий, забитий елемент, слабо охоплений впливом професійної спілки. Неорганізовані, безпорадні батрачки нещадно експлуатуються. У сільському господарстві сільськогосподарського технікуму завідувач Ковальов примушував робітниць улітку та восени босих, голодних та роздягнутих працювати в полі від зорі до зорі. Коли польові роботи завершилися і батрачки поралися біля худоби, чистили сараї, працювали на кухні, тривалість робочого дня не зменшилася. Скаржитися жінки боялися. За тяжку, виснажливу працю отримували копійки. Мешкали в приміщеннях темних, сирих, холодних. Харчі були мізерними та недоброякісними. Ще гірше жилося батрачкам у приватних господарів - болгар, які мали широкій простір для вижимання поту, оскільки існувала повна відірваність від спілки «Всеробземліс» (професійною спілккою робітників землі і лісу, яка діяла в УСРР у 20-ті роки ХХ ст.). Один тільки город виділявся - город Топовочарова. Працювало в ньому до 30 робітниць. Умови трудового договору суворо додержувалися. Знаходився договір на видному місці, кожна робітниця знала свої права та обов' язки. А господарство Топовочарова розвивалося не тільки не гірше, а навіть краще, ніж в інших господарів [16, с. 2].

Як бачимо, умови праці найманих робітників, особливо не охоплених «Всеробземліс», були однаково тяжкими в українських селах. Сільськогосподарські робітники виконували переважно малокваліфіковану роботу, пов' язану з важкою фізичною працею. Оскільки домашнє господарство виступало як частина виробничого процесу, наймані робітники виконували різноманітну роботу, тривалість робочого дня із закінченням польових робіт не зменшувалася, побутові умови були тяжкими тощо, але перед страхом втратити й таку роботу наймити продовжували працювати не скаржачись.

Робочий день батраків був подовжений. Іншого бути й не могло, тому що законодавство передбачало робочий день за домовленістю між сторонами. Вихідними днями батрацтво не користувалося та ніякої компенсації за це не отримувало, хоча такий пункт у договорі було зазначено [11, арк. 68].

Нерозвиненість товарно-ринкових умов, низький рівень освіченості й культури наймитів призводили до численних і грубих зловживань із боку наймачів. Дуже часто вони були пов' язані з різними економічними злочинами та зловживанням службовим становищем, що випливало із недосконалості радянського законодавства [17, с. 93-94].

Влада проводила роботу серед батрацтва, по-перше, з метою залучення на свою сторону та протиставлення заможним верствам селянства; по-друге, використовуючи як необхідну в умовах відбудови робочу силу. Робота серед батрацтва проходила з метою виявлення й охоплення його трудовими договорами, а також залучення до членства профспілок і роз' яснення необхідності сплати членських внесків [12, арк. 142]. Батрацтво було «важливою класовою опорою партії на селі» [13, арк. 53], тому партія рекомендувала відділенням профспілки робітників землі і лісу домагатися підвищення заробітної плати наймитів, вимагати встановлення оп- 
лати праці батрацтва грошима, а не натурою; боротися проти оплати праці батраків обробкою наймачем їхньої землі; при встановленні заробітної плати у вигляді одягу, зерна тощо обов' язково обговорити якість та цінність натури; відстежувати, щоб заробітна плата наймита забезпечувала його на зиму, коли він залишиться безробітним, оскільки робота в сільському господарстві є сезонною. Щодо робочого часу, то домогтися, щоб «усе батрацтво користувалося вихідними днями, звернувши при цьому особливу увагу на пастушество» [11, арк. 73-74.]. Незважаючи на такі заклики партійного керівництва, робота профспілок на місцях була формальною та значного впливу на працю та життя наймитів не мала.

Для жінок-наймичок друкувався журнал «Батрачка» - орган центрального комітету професіональної спілки сільськогосподарських робітників СРСР. У ньому публікувалися актуальні для батрачок поради з юридичних, медичних, господарських питань, наприклад: як прати картоплею, коли немає мила, якими повинні бути умови проживання [14, с. 4, 16], чому самогон - найлютіша отрута [18, с. 1], як пошити сукню [19, с. 15] тощо. Але журнал мав, скоріше, агітаційно-пропагандистський характер, реальної допомоги жінкам-наймичкам щодо захисту їхніх прав не надавав. 3 іншого боку, назви порад свідчать про труднощі, $з$ якими стикалися селянки-батрачки в повсякденному житті.

Білышовицька влада, починаючи з грудня 1927 р., поступово обмежує використання найманої праці в сільському господарстві. Постановою Політбюро ЦК ВКП(б) «Про заходи по ліквідації куркульських господарств у районах суцільної колективізації» від 30 січня 1930 р. використання найманої праці на селі взагалі було заборонено.

Висновки. Отже, у 20-ті рр. XX ст. унаслідок легалізації оренди землі та використання найманої праці в сільськогосподарському виробництві сформувалася соціальна категорія сільського населення - батрацтво. Резервом робочої сили для нього слугували пролетарські елементи, які жили виключно за рахунок продажу своєї пращі (безземельні селяни), а також верстви, які являли собою напівпролетарську групу села (малоземельні селяни). Разом вони навіть наприкінщі НЕПу складали в Донбасі третю частина селянства. За статтю це були переважно жінки, чоловіче населення сіл Донбасу, як правило, знаходило заробіток у промисловості. За віком це були дорослі, підлітки та навіть малолітні (діти віком до 12 років). Останні дві групи користувалися попитом, оскільки нерідко роботу вони виконували нарівні 3 дорослими, а заробітну плату отримували набагато меншу. За тривалістю роботи за наймом батраки поділялися на рокових та строкових, поденних і здільних. Більшість наймитів намагалися знайти рокову та строкову роботу, бо вона була більш тривалою та забезпечувала хоч якусь стабільність існування. Робочий день наймитів був найдовшим із усіх працівників, про дні відпочинку навіть не йшлося.

Повсякденне життя та побут батрацтва, міцно пов'язані з тяжкою фізичною працею, були невлаштованими, рівень життя занизький. Зароблених коштів не вистачало навіть на поточні потреби, не те що на зиму.

Батрацтво було класовою опорою партії на селі, проте робота більшовицької партії та професійної спілки робітників землі і лісу щодо захисту прав наймитів була формальною та зводилася переважно до гасел та публікацій у пресі. Законодавство у сфері сільського господарства було недосконалим, що дозволяло наймачам його 
порушувати. Наприкінщі 20-х років XX ст., у зв' язку з розкуркулюванням та колективізацією, батрацтво Донбасу, як і всієї України, мало тенденцію спочатку до скорочення, а на початку 1930 р. використання найманої праці на селі взагалі було заборонено.

\section{Використані джерела:}

1. Ганжа О. І. Українське селянство в період становлення тоталітарного режиму (19171927). Відп. ред. С. В. Кульчицький. Київ : НАН України. Ін-т історії України, 2000. 208 с.

2. Кодекс законов о труде 1922 г. Харьков, издание народный комиссар юстиции, 1922. 63 c.

3. Временные правила об условиях применения подсобного наемного труда в крестьянских хозяйствах. Постановление СНK СССР от 18 апреля 1925 года. URL : http:// www.alppp.ru/law/trud-i-zanjatost-naselenija/trud/152/postanovlenie-snk-sssr-ot-18-04-1925. html. (дата звернення: 01.12.2020).

4. Курдюмова Е. А. Донбасс на подъеме (1921-1925 гг.): Исторический очерк. Под ред. д-ра ист. наук 3. Г. Лихолобовой. Донецк, 1976. 143 с.

5. Україна. Статистичний щорічник. 1929 р. Харків, 1929. 399 с.

6. Державний архів Донецької області. Ф. 1. Оп. 1. Спр. 2045. 77 арк.

7. Збірник статистико-економічних відомостей про сільське господарство України. Вип. І. Харків : «Господарство Украӥни», 1929. 348 с.

8. Лях С. Р. Наймана праця в сільському господарстві України в умовах НЕПу. Київ : Вища школа, 1990127 с.

9. Україна. Статистичний щорічник. 1926 р. Харків, 1926. 407 с.

10. Державний архів Луганської області (далі - ДАЛО) Ф. П-34. Оп. 1. Спр. 145. 65 арк.

11. ДАЛО. Ф. П-34. Оп. 1. Спр. 125.74 арк.

12. ДАЛО. Ф. П-34. Оп. 1. Спр. 55.101 арк.

13. ДАЛО. Ф. П-34. Оп. 1. Спр. 923.24 арк.

14. Как стирать картошкой, когда нет мыла. Батрачка. 1928. № 5. С. 4.

15. Статистика труда в Донбассе. Артемовск, 1925. 64 с.

16. Как живут батрачки. Луганская праљда. 1924. 23 ноября. № 86.

17. Смирнов В. М. Суспільно-політичні та економічні перетворення в українському селі в період нової економічної політики. Харків : Майдан, 2002. 304 с.

18. Самогон - злейшая отрава. Батрачка. 1928. № 3. С. 1.

19. Наше рукоделие. Батрачка. 1928. № 1. С. 15.

\section{References:}

1. Hanzha, O. I. (2000) Ukrainske selianstvo v period stanovlennia totalitarnoho rezhymu (1917 - 1927). S. V. Kulchytskyi (Ed.). Kyiv : NAN Ukrainy. In-t istorii Ukrainy. [in Ukrainian].

2. Kodeks zakonov o trude 1922 h. (1922) Kharkiv, izdanye narodnyi komyssar yustitsii. [in Russian].

3. Vremennye pravila ob usloviyah primeneniya podsobnogo naemnogo truda $\mathrm{v}$ krestyanskih hozyajstvah. Postanovlenie SNK SSSR ot 18 aprelya 1925 goda. (1925) URL : http: //www.alppp.ru/law/trud-i-zanjatost-naselenija/trud/152/postanovlenie-snk-sssr-ot-18-041925.html. [in Russian].

4. Kurdyumova, E. A. (1976) Donbass na podeme (1921-1925 gg.): Istoricheskij ocherk. Z. G. Liholobovoj. Doneck. [in Russian].

5. Ukraina. Statystychnyi shchorichnyk. 1929 r. (1929) Kharkiv. [in Ukrainian].

6. Derzhavnyi arkhiv Donetskoi oblasti. F. 1. Op. 1. Spr. 2045. 77 ark. [in Ukrainian]. 
7. Zbirnyk statystyko-ekonomichnykh vidomostei pro silske hospodarstvo Ukrainy. (1929) Issue I. Kharkiv : «Hospodarstvo Ukrainy». [in Ukrainian].

8. Liakh, S. R. (1990) Naimana pratsia v silskomu hospodarstvi Ukrainy v umovakh nep. Kyiv : Vyshcha shkola. [in Ukrainian].

9. Ukraina. Statystychnyi shchorichnyk. 1926 r. (1926) Kharkiv. [in Ukrainian].

10. Derzhavnyi arkhiv Luhanskoi oblasti (dali - DALO) F. P-34. Op. 1. Spr. 145. 65 ark. [in Ukrainian].

11. DALO. F. P-34. Op. 1. Spr. 125.74 ark. [in Ukrainian].

12. DALO. F. P-34. Op. 1. Spr. 55. 101 ark. [in Ukrainian].

13. DALO. F. P-34. Op. 1. Spr. 923.24 ark. [in Ukrainian].

14. Kak stirat kartoshkoj, kogda net myla. (1928) Batrachka - Cottager, 5, 4. [in Russian].

15. Statistika truda v Donbasse. (1925) Artemovsk. [in Russian]. Russian].

16. Kak zhivut batrachki. (1924) Luhanskaya pravda- Luhansk truth,1924, 23 noyabrya, 86. [in

17. Smyrnov, V. M. (2002) Suspilno-politychni ta ekonomichni peretvorennia v ukrainskomu seli v period novoi ekonomichnoi polityky. Kharkiv, Maidan. [in Ukrainian].

18.Samohon - zleishaia otrava. (1928) Batrachka - Cottager, 3, 1. [in Russian].

19. Nashe rukodelye. (1928) Batrachka - Cottager, 1, 15. [in Russian].

Стаття надіӥшла до редколегї̈ 02.12.2020

Матвєєва Л. Г., доктор юридических наук, доцент, заведующая кафедры теории и философии права Одесского государственного университета внутренних дел (г. Одесса, Украина)

Тарасенко Л. Б., кандидат исторических наук, доцент, профессор кафедры теории и философии права Одесского государственного университета внутренних дел (г. Одесса, Украина)

\section{ПРАВОВОЕ И СОЦИАЛЬНОЕ ПОЛОЖЕНИЕ БАТРАЧЕСТВА В СЕЛАХ ДОНБАССА В ГОДЫ НОВОЙ ЭКОНОМИЧЕСКОЙ ПОЛИТИКИ (В КОНТЕКСТЕ ПОВСЕДНЕВНОСТИ)}

В статье исследуются особенности правового и социального положення батрачества Донбасса в годы новой экономической политики, его труда и быта. В годы неповских преобразований начались значительные сдвиги в социальной структуре крестьянства. Особенности земельной политики советского государства этого периода, в частности, легализация аренды земли и наземного труда в сельскохозяйственном производстве открыли определенные возможности для развития индивидуального крестьянского хозяйства, при этом разрешался определенный рост капиталистических элементов села под контролем государственных органов. Однако с другой стороны ухушалось экономическое положение малоимущих хозяйств, вследствие чего сформировалась достаточно сложная социальная катогория сельского населения, которое жило за счет продажи свого труда, - батрачество. 
В статье, среди прочего, использованы документы и материалы, которые хранились в Государственном архиве Донецкой области и Государственном архиве Луганской области и сейчас, по известным причинам, являються недоступними для исследования.

Ключевые слова: НЭП, сельское хозяйство, батрачество, аренда земли, наёмный труд.

Matvieieva L.,

Doctor of Law, Docent,

Head of the Chair of Theory and Philisophy of Law

Odesa State University of Internal Affairs

(Odesa, Ukraine)

Tarasenko L.,

Candidate of Historical Sciences, Associate Professor, Professor, Department of Theory and Philisophy of Law

Odesa State University of Internal Affairs

(Odesa, Ukraine)

\section{LEGAL AND SOCIAL POSITION OF COTTARS IN THE DONBASS VILLAGES DURING THE NEW ECONOMIC POLICY (IN THE CONTEXT OF EVERYDAY LIFE)}

During the NEP reforms significant changes began in the social structure of peasantry. The peculiarities of the Soviet state's land policy of this period, in particular, legalization of land lease and wage labor, certain opportunities appeared for development of individual peasant farming, and certain growth of capitalist elements of village was allowed under the state bodies' control. On the other hand, economic situation of poor households worsened, which resulted in formation of a rather complex social category of rural population, which lived on the sale of their labor, farm work.

In the Donbass the number of farm laborers in agricultural production was relatively small. However, not only landless, but also land-poor peasants with a crop of 1 to 4 dessiatines turned to servile labor as a source of income. Their total in 1923 was $47.8 \%$ of the total of Ukrainian peasantry, and in 1928 it was 33.1\%, that is, there was a huge army of the rural population, which needed systematic work outside their own farm. The article states that based on seasonal nature of agricultural production, as well as economic necessity, employers hired farm laborers for annual, temporary, day and piecework work.

It means that almost always the salary was given to the farm laborers in exterior and the quality of products, things, etc. was not specified anywhere. Signing up a contract, the subsistence minimum was not taken into account so the majority of farm laborers did not provide themselves for the winter. Attention is drawn to the fact that the working and living conditions of the farm laborers were very difficult. The features of the social position of the servants of Donbass during the years of New Economic Policy, their work and life are explored in the article.

In 1925 labor relations in the countryside were allowed by the state party and were growing until the late 1920s. With the onset of the "onslaught" and collectivization, there was a gradual reduction and prohibition of hired farmwork.

Keywords: NEP, agriculture, farm work, land rent, wage labor. 